\title{
LEER EN EL UMBRAL: \\ APUNTES SOBRE LA FUNCIÓN DEL LECTOR EN LA LITERATURA GUINEO-ECUATORIANA
}

\author{
POR \\ Dolores Aponte-Ramos \\ Universidad de Puerto Rico
}

A Clelia Rodríguez, este texto hermanado al suyo

Yo soy Lola Aponte y soy lectora. Confieso mi hábito rayano con lo adictivo, frente a ustedes lectores de un texto que pretende esclarecer las funciones que se nos asignan desde el texto, nuestro tirano. Carente de un programa de 12 pasos y sin ánimo de explicar más, les diré que fui inducida a la lectura por mi abuelo tabacalero, que en mi país tradujo a anarquistas de fincas pequeñas, quienes leían a viva voz y sin demasiadas distinciones a Tolstoi o Bécquer mientras se cosía el tabaco, se bebía, se conspiraba y se amaba. Tabaco, ron, letra y anarquismo: todo lo prohibido. Desde esa autobiografía leo y escribo sobre el oficio de leer, en la posicionalidad especial de fungir como lectora de la novela guineo-ecuatoriana.

Relatar la función de lector en la novela guineo-ecuatoriana supone escudriñar la relación del escritor con la letra y cómo éste delinea el proceso de recepción de su texto, literatura escrita en español dentro del archipiélago Guineo-ecuatoriano y en el exilio. Para ilustrar estas funciones adscritas al lector desde el texto visitaremos tres escritores, dos coloniales y uno contemporáneo: Leoncio Evita de Cuando los Combes luchaban (1953), Daniel Jones Mathama, La última lanza para el boabi (1962); y Juan Tomas Ávila Laurel, Arde el monte de noche (2009), este último leído en contrapunto con su página de Facebook del 2010 y aquella en apoyo al escritor.

\section{LECTURA Y ORATURA, ALGUNAS CONSIDERACIONES SOBRE LAS TECNOLOGÍAS NARRATIVAS}

La lectura ya lo dijo Platón es un diálogo mudo y fijo en que uno de los hablantes no responde. La mudez es alterna, en el momento de la escritura el lector es ausente/ silente, al leer el escritor solo puede hablar a través de la letra fija. Desconfiaba así Platón de la lectoescritura, una tecnología que atentaba contra la epistemología dialógica y la preservación misma de la historia humana. Leer es pues un diálogo de locos en que la 
interpelación nos llega de ultratumba, o la distancia, aún en la fingida inmediatez del "texting", el "chateo" y otros formatos a los que aludiremos brevemente en este mismo trabajo. El escritor de los Diálogos -nótese la summa de contradicciones- no esperaba respuesta del autor, ése era su desencanto, no esperaba permanencia de lo escrito por la fragilidad misma del medio, dado como sabemos a podrirse o resquebrajarse. Sócrates le aclara a Fedro que:

Éste es, mi querido Fedro, el inconveniente, así de la escritura como de la pintura; las producciones de este último arte parecen vivas, pero interrógalas, y verás que guardan un grave silencio. Lo mismo sucede con los discursos escritos: al oírlos o leerlos crees que piensan, pero pídeles alguna explicación sobre el objeto que contienen, y te responden siempre la misma cosa. Lo que una vez está escrito rueda de mano en mano, pasando de los que entienden la materia a aquellos para quienes no ha sido escrita la obra, sin saber, por consiguiente, ni con quién debe hablar, ni con quién debe callarse. Si un escrito se ve insultado o despreciado injustamente, tiene siempre necesidad del socorro de su padre, porque por sí mismo es incapaz de rechazar los ataques y de defenderse. (Fedro 274c-277a)

Mucha de esta fragilidad enfrenan los escritores guineo-ecuatorianos coloniales inscritos en un mundo de sumadas censuras y desconocimientos. Mundos que convergen artificialmente en ese invento llamado escritura, tecnología que le hacía sospechar al filósofo griego y que asume el escritor colonial a sabiendas de sus entramadas trampas y su posibilidad de silencios desde el público receptor. En el Fedro se nos explica de cómo un hablante desconocía al otro, desconocimiento que hace imposible toda interpelación real entre logos. Así mismo, para el escritor de Guinea Ecuatorial, un mundo desconoce al otro, un mundo es nombrado a partir de los colonizadores y de voces autorizadas por éstos quienes desconocen del mundo africano que produce la escritura.

La oratura desaparecía en manos de la inconstancia de lo escrito, el apalabramiento en el mundo occidental es una promesa generalmente incumplida. Por ello le toca al autor guineo-ecuatoriano, como había predicho Platón en otras latitudes y tiempos, en vivo a partir de entrevistas, aclaraciones y comunicaciones cibernéticas, defender su escrito muerto. Esta posibilidad avistada por el personaje Sócrates, adquiere una realidad de inmediatez en la novela colonial de Guinea Ecuatorial y luego de manera más inmediata en el mundo cibernético. Sumar ése lector mudo u olvidadizo al "proyecto libro" es una estrategia que adquiere diversos formatos expresivos en manos del escritor colonial guineo-ecuatoriano; y que a vuela pluma relataremos en las siguientes páginas.

En esa misma coyuntura de encuentro de la letra y la oratura, en un mundo dialogante sin respuestas, escribiendo con la carencia dela cultura lectora se encuentran los escritores coloniales Leoncio Evita, autor de Cuando los combes luchaban (1953); novela de costumbres de la antigua Guinea Española y Daniel Jones Mathama en La última lanza para el boabi (1962).

Revista Iberoamericana, Vol. LXXX, Núms. 248-249, Julio-Diciembre 2014, $1081-1095$ ISSN 0034-9631 (Impreso) 


\section{GEOGRAFÍAS TRASLAPADAS DEL LECTOR}

Para Platón como para los escritores africanos de Guinea Ecuatorial en este ensayo examinados, el lector carece de memoria, lo que implica tanto una cierta incapacidad para decodificar el texto como una ubicación de traslape en el locus cognitivo. El lector es, ante todo, un morador del olvido, que recupera un facsímil imperfecto de un diálogo imposible. Desde sus inicios esta suerte de olvido parece marcar la letra guineo-ecuatoriana. Asumido como coyuntura genética de los escritores de Guinea Ecuatorial colonial, el olvido está imbricado en los loci del lector en tres instancias que nombramos a continuación. Así pues, o proviene de la cultura de predominancia de oratura; o se trata de un letrado de un centro cultural occidental, sea por ejemplo España; o es un africano de la misma geografía cultural que el escritor. ${ }^{1}$ Ese lector ante el texto guineo-ecuatoriano del periodo colonial está ubicado en el centro de la cultura letrada, es aquel que mira con desdén y espíritu corrector el texto que tiene frente a sí o en maravillada curiosidad ante la evidencia de una novela africana, imposible gesto cultural. Documento inexorable, la escritura de sujetos pensantes, de subalternos con voz propia que reclaman los mismos útiles expresivos del centro, la novela guineoecuatoriana coloca a su lector siempre en una dimensión política de la lectura, esa es la geografía última.

Al lector que no se contempla como receptor capaz de producir una hermenéutica del texto en esta literatura colonial, ni es aquel informado, ni aquel compartidor de claves que le permitan esclarecer el texto. Por varias razones: la especificidad tribal de cada relato, combes y boabí, etnias minoritarias, la localización del narratio en un pasado recuperado desde la creación novelesca, y la pertenencia a culturas de importantes tradiciones de oratura, el escritor mismo es un poco foráneo a su narratio, es un padado que se recupera en la escritura. Así las cosas, conviene añadir a este tinglado tan intrincado que la novela es todavía un ente extraño, una tecnología escritural del colonizador cuyo acceso está determinado por las geografías culturales que inciden en las mismas.

A partir de todo ello, el escritor guineo-ecuatoriano reclama una ubicación a ambos lados del adentro/afuera, mientras que sus lectores ubicados a uno u otro lado de dicho locus carecen de todas las claves decodificadoras. Más complicado aún: el adentro es un afuera. El escritor en su gesto de novelar provoca su insilio, reclama una forma de extranjería, muy parecida a aquellas identidades transitorias que Victor Turner nombraba "between and betwixt". Se ubica en la línea fronteriza misma, en la raya que contemplamos en los mapas, en la liminaridad del dintel, en el umbral.

\footnotetext{
Nótese que muchos críticos de la literatura guineoecuatoriana son africanos exiliados que han hecho estudios en español. M'bare N'gom, punta de lanza en el estudio de esta literatura, es de Conakry, Victorian Lavou es congolés, George Nana es camerunés, mientras Clement Akassi es de Costa de Marfil, Moses Panford, Gde Ghana, entre otros.
}

Revista Iberoamericana, Vol. LXXX, Núms. 248-249, Julio-Diciembre 2014, 1081-1095 ISSN 0034-9631 (Impreso) ISSN 2154-4794 (Electrónico) 
Leer supone colocarse en el vano de la puerta sígnica. Esa posicionalidad supondrá un gesto dinámico, en el que las correspondencias signo/decodificación no son una sino múltiples. ${ }^{2}$

La cultura lectora, tiene particularidades que nos importa ir aclarando a medida que avanza el texto. Para ello echaremos mano de Derrida, Isen, Eco, Jauss y Kristeva, ${ }^{3}$ entre otros.

\title{
EL LECTOR, ESE GRAN AUSENTE
}

Resulta primordial anotar que leer es regularmente un acto ausente. Nos ausentamos del entorno, de aquello que nos rodea, para asumir el espacio nombrado desde el símbolo descifrado. Nos alejamos incluso del emisor /autor quien es igualmente un ausente. Nos alejamos del escritor para reclamar tenencia de la letra, autoría de significaciones. En un lado más optimista de ese ejercicio Wolfang Iser nos propone a ese ausente como un creativo productor de significaciones en las que interviene su experiencia vivencial, que nombra como indeterminación. Traza la indeterminación en dos espacios vitales entre el lector y el texto, y entre el texto y la realidad

\begin{abstract}
Although the literary text incorporates conventions that may provide a degree of common ground between itself and the reader, these conventions tend to be organized in such a way that their validity is, at best, called into question. The new arrangement of old norms constitutes one of the risks, as it is not related to the reader's own disposition, and another risk lies in the fact that, in contrast to ordinary speech acts, the literary text has no concrete situation to refer to. Indeed, it is this very lack of an existing situation that brings about two ranges of indeterminacy: (1) between text and reader, (2) between text and reality. The reader is compelled to reduce the indeterminacies, and so to build a situational frame to encompass himself and the text. Unlike the situational frame presupposed by the speech-act theory, the fictional situation does not exist until it is linguistically produced, which means that it is bound to be different in character and consequences from one that is already given and defined. (The danger here is that the very openness of the text may prevent the establishment of common ground; the advantage, however, is that there must then be more than just one for of interaction). (Isern 2; énfasis nuestro)
\end{abstract}

Este proceso de la necesidad de la ausencia/indeteminación para el acto de leer es un espacio de inquietud en el ars poética del escritor colonial guineano, quien escribe

2 Visitamos aquí como sustrato teórico a Umberto Eco, quien inspirado a su vez en el modelo de Janos Ptofi propone el cuadro de niveles de cooperación textual. En dicho cuadro las correspondencias percibidas por el lector son mútiples.

3 Aclaro qe los escritores guineanos en general son muy conocedores de los espacios teóricos europeos a los que aluden en sus textos, así como de la cultura grecolatina.

Revista Iberoamericana, Vol. LXXX, Núms. 248-249, Julio-Diciembre 2014, 1081-1095 ISSN 0034-9631 (Impreso) ISSN 2154-4794 (Electrónico) 
para dar cuenta de su mundo. Mundo de la letra que invoca para relatar mientras borra, por los procesos de indeterminación que contempla Isern en su propuesta. En efecto esa doble ausencia/doble indeterminación de alguna manera es puesta a prueba(¿revertidora?, ¿nulificadora?) por la novela guineo-ecuatoriana y su necesidad de relatar su mundo, dar constancia de sus vivencias. Contemporáneamente el escritor participará a menudo de la explicación del texto. En el mundo colonial la entrevista, el prólogo y, en el caso de Evita, las ilustraciones del texto hechas por el propio escritor suponen una manera de disolver la distancia entre el marco de producción textual y el receptor. La novela contemporánea, producida en el fragor del mundo del escritor, figura mediática, mantiene dominio sobre la interpretación, pues es un ente a quien entrevistamos, enviamos correos electrónicos o quien está en nuestra lista de amigos de Facebook.

La novela africana en general y la guineo-ecuatoriana en particular se suma a otro tipo de ausencia/indeterminación. Se escribe muchas veces en un mundo -físico o mental- en que la oralidad ha sido el recurso privilegiado para la narrativa. Se escribe además, en muchos casos para lectores cuyos imaginarios de África coinciden con nociones de "el continente oscuro", habitado por leones o tribus guerreras. Ambos títulos de las novelas apuntan a ese imaginario.

$\mathrm{Si}$ el escritor debe entonces construirse a contrapelo de sus geografías -la natal, la del exilio, la insílica y la receptora-igualmente debe reinscribir la función del lector. Esta multiplicidad escritural del escritor colonial guineano pone de manifiesto la imposibilidad de verificación de sentido que Wolfgang Iser (1972) señala es producto del gestual de Konkretisier. Ese gestual supone validar sin sanar la grieta entre el lado artístico - "que remite al texto creado por el autor"- y la concretización que realiza el lector. Dicho de otra manera, esta vez por Julia Kristeva, se trata de la distancia entre el genotexto del escritor y el decodificado por el lector, el mismo objeto, no el mismo texto.

Esa grieta/ disntancia a que apuntan ambos teóricos, se vuelve fundamental en la escritura guineo-ecuatoriana. Si la explicamos en términos de la autora de Ensayos de semiótica poética tanto el lector como el escritor poseen diferentes campos significativos por los que el texto deviene un objeto dinámico, transformativo en cuanto práctica "de la trasposición del genotexto al fenotexto", proceso que explica la teórica de la siguiente manera:

Llamaremos texto a toda práctica del lenguaje mediante la cual se despliegan en el fenotexto las operaciones del genotexto intentando el primero representar al segundo, e invitando al lector a reconstruir la significancia. (284)

Esta distancia supone que el texto leído no es el texto escrito y el lector es dueño de la significación sin necesidad de guía del autor. En estos procesos los textos se plantean el proceso dinámico hacia la posibilidad de una interpretación cercana al proceso de producción. Para ello el autor sigue dos relaciones con el proceso de interpretación:

Revista Iberoamericana, Vol. LXXX, Núms. 248-249, Julio-Diciembre 2014, 1081-1095 ISSN 0034-9631 (Impreso)

ISSN 2154-4794 (Electrónico) 
la primera, donde se concede la autoridad al exégeta; o la segunda, donde se le guía para alcanzar una interpretación de la significancia cercana al proceso de producción.

Cuando los combes luchaban, publicada en 1953, es la primera novela guineoecuatoriana ilustrada por el escritor mismo, Leoncio Evita. El autor hace dos concesiones al lector occidental: provee al libro de un prólogo y realiza dibujos cercanos a los grabados de enciclopedias y manuales instructivos, dibujos con gran valor explicativo. ${ }^{4}$ Leoncio Evita enfrenta el problema de validación de la voz del subalterno entregando el capital interpretativo a un prologuista, que funciona como mediador entre el mundo culto que el escritor espera reciba su obra y el margen desde el cual se produce la obra. Carlos González Echegaray explica su proceso como lector privilegiado quien asume el acto de escritura como uno de búsqueda de legitimación del africano colonial, por lo que elimina del texto: "algunas construcciones excesivamente extrañas a nuestra sintaxis y algunos errores de propiedad en la aplicación de vocablos castellanos" (3).

El lector prologuista en este texto, es un censor, quien se adjudica funciones del autor sobre quien interviene con las reglas y reglamentaciones del buen decir. Es un lector que precede el acto de lectura de otros receptores y los/nos alecciona sobre nuestro proceso mismo de recepción. El prologuista tiene como tarea disolver la indeterminación del signo. Para ello se adjudica el proceso de normalizar el espectro significativo transformativo que en este caso supone tiempos, culturas, visiones de mundo e historias diferentes. Si para Isier el lector es el factor primordial del texto, en este caso el lector prologuista intefiere y opta por mitigar el acto de recepción, a favor de palearlo para nosotros. El apoderamiento que significa leer, pretende ser contenido por la corrección y la traducción de un mundo en otro a manos del prologuista interventor. El prologuista parte de la duda:

En un hermoso y esclarecedor ensayo sobre la función del prologuista en Cuando los combes luchaban en ese caso en unión al prólogo de Ekomo de María Nsué, Vicente Granados Onomo-Ala Université de Yaoundé de Camerún propone que: Carlos González y Vicente Granados parecen detener las "llaves" que abren el mercado de los bienes simbólicos a la literatura guineana como parecen detener las "llaves" de las instancias que confieren la legitimidad a dicha literatura. Sus prefacios son pues fundamentales para determinar los diferentes aspectos del sujeto cultural colonial balizando el discurso ideológico de la instancia préfacielle; un discurso que se construye en torno a las parejas antitéticas colonizador/colonizado; superioridad/inferioridad; capacidad/incapacidad; dominante/ dominado. Este discurso es regulado río arriba por la ideología de la raza superior del colonizador que establece la sinonimia "indígena = no-evolucionado". Siempre en el prólogo a la 2 da edición, Carlos González reconoce que "naturalmente,

4 Dedico el artículo "La novella como graffiti. Cuando los combes luchaban de Leoncio Evita novella ilustrada" (en prensa), a las ilustraciones del texto, por lo que solo haré referencia a la existencia de los dibujos en este texto.

Revista Iberoamericana, Vol. LXXX, Núms. 248-249, Julio-Diciembre 2014, 1081-1095 ISSN 0034-9631 (Impreso)

ISSN 2154-4794 (Electrónico) 
tanto a lo largo de la novela, como en mi prólogo - mea culpa-, se advierte claramente la influencia del pensamiento oficial sobre la colonización". (14)

El prólogo vuelve a ser así un espacio de negociación o si se prefiere de tensión entre el prologuista y la sociedad destinataria que va a leer la ob

La estrategia de mostrar el mundo narrado a partir de elementos visuales, gracias a la maestría del dibujo de Evita permite al lector ubicarse en una geografía desde la cual leer. Si bien dedico otro texto a la imagen-texto e imagen en Leoncio Evita como parte del

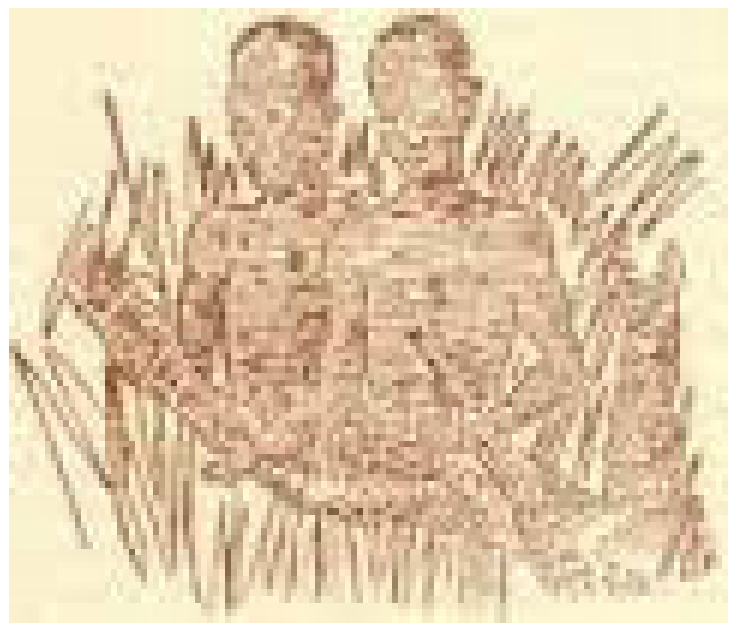
desarrollo de la posicionalidad del lector ante la producción textual guineo-ecuatoriana resumo algunos postulados aquí. La esencia del dibujo de Evita, quien se consagra después de esto a su vida como ilustrador, no es una propuesta de mimesis primitivista. Supone la aceptación artística de que el receptor del texto visual manifestará los mismos problemas de distanciamiento y ausencia de marco interpretativo que el del lector. Evita nos presenta un espacio dialógico en el cual propone diversas maneras de posicionamiento del receptor ante el sujeto relatado/ilustrado. Con ello muestra aun más la complejidad de las relaciones audiencia, artista-sujeto, lenguaje y su relación última con las estructuras de poder que modifican la relación entre escritor y lector. La exploración de hacer el lenguaje novelístico visible, incide en las posibilidades de asociar lo verbal y lo visual al construir imágenes como la que colocamos aquí, en la que se extiende el espectrum disyuntivo del texto. Me temo que antes de hacerlo más familiar y degustable al lector de la España franquista lo torna más disociador y ajeno.

El africano semidesnudo en una maleza y sujetando armas extrañas incide en el imaginario que el europeo ha construido. Ninguna forma de civilidad común es percibida allí.

Al lector se lo siente tan foráneo, que debe dotársele de imágenes con que deconstruir el texto. Las imágenes no relatan el texto, sirven para dar carnosidad a ese imaginario. Para proveer de anclaje visual a lo inimaginable.

Revista Iberoamericana, Vol. LXXX, Núms. 248-249, Julio-Diciembre 2014, 1081-1095 ISSN 0034-9631 (Impreso)

ISSN 2154-4794 (Electrónico) 
La materialidad del texto como conflicto, la percepción del lector como exógeno se subraya con la multiplicidad de códigos a los que nos expone el autor: texto escrito, texto visual y texto meta/interpretado por un prólogo. El lector es guiado hacia una hermenéutica posible.

\section{EL LECTOR COMO PERSONAJE}

Daniel Jones Mathama en Una lanza para el boabí (1962) reclama al lector de manera abierta en cuanto partícipe mismo del texto. La estrategia consiste en que lo coloca como personaje de su texto; el proceso de leer es parte del gesto escritural del guineoecuatoriano quien escribe. Si bien puede aludirse a la usanza novelesca decimonónica en que el lector de la novela era interpelado, el caso de Jones Mathama es singular. Tomemos como punto de partida la advertencia con que comienza el texto. En España de 1962 esa excusa parapeta la imposibilidad de hablar desde África, ya que es España quien articula el habla hacia África. La apalabrada es la España franquista. La letrada. Y en nada modesta contradicción con ese mundo colonial desde donde se articula con colegios religiosos la voz europea del colonizado. En Una lanza ese doblete dialógico de mudez/articulación de voz/ incorporación a las letras hispánicas y demarcación de diferencia africana se articula con la presencia del "amable" una veces y otras "querido" lector, tan presente que funge a mi modo de ver como personaje.

El lector atestigua las ambivalencias del escritor mismo al enfrentar su proceso de redacción creativa de recuperación de un mundo al cual ya el propio autor es ajeno. Nación se vuelve recuperación de infancia. Para ello hace varios asedios. Su primera estrategia, posicionarse como lector él mismo para instalarse en la disolución de su diferencia mientras se apropia de la tradición letrada: "Cómo quisiera parecerme a alguno de aquellos hijos que heredaron el ingenio del manco de Lepanto; grande es mi satisfacción cuando leo un artículo o novela escritos con maestría" (3).

No deja de ser curioso que el escritor guineo-ecuatoriano sea políglota y escriba varias novelas en inglés; pese a ello, no se siente autor/izado a escribir. Nótese que este posicionamiento de la imposibilidad pretende justo lo opuesto: colocarlo como escritor bona fide en la herencia hispánica de las letras. Se presenta a sí mismo tanto como lector con capacidad de discernir la calidad de escritura. Es conocedor/heredero del Manco de Lepanto, canon de lo que constituye la buena escritura, esa que le satisface.

En esa primera tentativa dialógica y siempre con humor añade que:

así pues antes de proseguir he de rogar al amable lector que disculpe la torpeza de mi pobre pluma porque ha de saber que cuando el hombre nace esta dotado solo de instintos y según el ambiente en que se desarrolla adquiere hábitos buenos o malos. Si al nacer lo enseñaran a llamar animal a una persona así lo haría sin olvidarnos que son muchos los que merecen ese calificativo. (2)

Revista Iberoamericana, Vol. LXXX, Núms. 248-249, Julio-Diciembre 2014, $1081-1095$ ISSN 0034-9631 (Impreso)

ISSN 2154-4794 (Electrónico) 
Esta cita es intrincada: al lector se le llama amable pero se tantea la posibilidad de su animalización o al menos se lo entiende como cómplice de nombrar la animalización de otros. Animalización transracial, desbordada en diferentes en/carnaciones, desnaturaliza la estrategia occidental de animalizar a sus sujetos coloniales y extiende el proceso de animalización a cuantos merezcan "ese calificativo" (loc.cit).

El gesto de llamar al lector hipotético "amable"y "querido"participa de algunamanera la adulación que es un lugar común propio del género del prólogo. Lo interesante es que su posicionamiento parece seguir el locus de definición de la ontología asignada por los centros de poder de lo africano como lo intuitivo cercano a lo primitivo /lo animal. En este corpus de significados las letras son un territorio en el que se mueve trabajosamente y el escritor de Una lanza parece apropiarse de ese mundo conceptual para revertirlo. Así pues, con el chiste sobre el adjetivo animal invierte ese mundo conceptual y lo vuelve un universal transfronterizo que lo re/significa hacia lo humano. Igualmente, al lector que responde con una carcajada o al menos con un gesto de asentimiento lo vuelve su cómplice en la translocación de la ideología dominante.

La presencia del lector le sirve para adueñarse de la escritura, pero el lector/ personaje, el lector dialógico permanece solo hasta la página 55 de la edición que manejo. $\mathrm{Y}$ ante ese lector, el escritor personaje se devela como el protagonista de esta historia, de recuperación de un mundo perdido y bildungsroman. El escritor como personaje, pues declara ser el niño Gue, centro narrativo, ante el lector como personaje. La letra es el escenario de la identificación de espacios de ubicación que generalmente no se encuentran entre personaje y escritor. En este caso, ambos constituidos en letra producen acuerdos de interpretación textual y trasposiciones de significación .

Difiere del escritor firmante el escritor personaje pues mientras la familia criolla Jones está en proceso de colocar una planta termodinámica justo en la fecha de la publicación de la novela, el escritor firmante desea mantener sin tocar la Guinea de su infancia. Gue es "otro" escritor que le proporciona de una alteridad con el instrumental de recuperación de la patria perdida, recuperación centrada desde la validez testimonial que el lector personaje dialógico posibilita.

Aprovecha al lector desde otros ángulos en el desarrollo de la novela en este propósito. Para el lector, el escritor hace apuntes antropológicos, aconseja al lector, embroma al lector, alecciona al lector, le dirige la mirada: "(Mira cómo se divierten aquellos chiquillos corriendo desnudos bajo la lluvia. Esto solo es posible en este país donde una sola gota de lluvia sirve para llenar un vaso pequeño de vino" (32). Nos preguntamos.

¿Quién es este lector? Es un curioso europeo al que hay que irle construyendo un África con un marco de referencialidad europea: la literatura a la que se cita, la ejemplaridad que se visita, las comparaciones nos hacen pensar en un estudioso o por lo menos en alguien con cierto grado de pulimiento con quien puede filosofarse sobre el

Revista Iberoamericana, Vol. LXXX, Núms. 248-249, Julio-Diciembre 2014, 1081-1095 ISSN 0034-9631 (Impreso)

ISSN 2154-4794 (Electrónico) 
paso del tiempo. Se trata de un lector tal que puede sentir solidaridad por un relato sobre boys mal pagados y timados por algunos "granujas" de hombres blancos. El lector, si nos dejamos llevar por la minuciosa descripción que hace el escritor de parajes selváticos, la reiteración de la ineficiencia de la palabra para conjurar el detalle exacto, parece estar ubicado en Europa, sin embargo su viaje mental se tiñe de fisicalidad cuando en una página nos sorprende:

Ahora verás los lugares donde Gue nació y vivió su infancia y quiero que al juzgarlo no pienses en él como los niños que has conocido y tratado; en una palabra te diré que muchos no lo condenarían y si alguno lo hiciera pecaría de un exceso de rigidez o de inconsecuencia. (55)

Y tras esta invitación un súbito cambio de planes para el lector frustra ese intento físico para convertirlo en un esfuerzo letrado:

ahora que te veo ya cansado de tanto andar te dejaré a bordo del Domine que regresa hoy a España y desearía que durante el viaje leyeras estas cuartillas que tratan con bastante exactitud sobre la vida de san Carlos y otros lugares en la época que Gue vivió en España. Adiós amigo buen viaje. (55)

El texto que sigue no dialoga con el lector. El escritor pasa de ser un guía de viajes a un narrador bona fide. El lector personaje desaparece, está en el barco leyendo el texto, suponemos. Leyendo desde un no lugar, desde una geografía móvil y trans-mutante. El texto que ahora asume el lector en el ocio del barco es aquel en que se relata la historia de Gue hacia su exilio. Al lector se lo deja con las cuartillas, asumiendo finalmente la independencia que el acto de leer supone. Mientras coloca el gesto de la lectura en un a/lugar mas allá de tiempo y la pertenencia geográfica.

Detengámonos aquí un instante y pensemos en ese acto impune y privado que es leer, atestiguar sucesos, vidas y paisajes desde un aquí y un ahora que las más de las veces es e inconexo con lo que se lee. El texto de Jones Mathama presenta una teoría de la lectura para el texto guineano que me provoca una serie de interrogantes, de las cuales comparto solo algunas:

- el lector hipotético es una persona que se constituye en un ente activo y participante, al modo de la lectura antropológica,

- se define como un res que enjuicia y pregunta,

- contribuye el lector a partir de tales preguntas a conformar el texto

- el lector es siempre un extranjero,

- debe tener el lector movilidad entre el espacio exílico desde el cual se narra y el espacio recuperado en cuanto narrado.

- el lector contribuye a la recuperación del mundo perdido,

Revista Iberoamericana, Vol. LXXX, Núms. 248-249, Julio-Diciembre 2014, 1081-1095 ISSN 0034-9631 (Impreso)

ISSN 2154-4794 (Electrónico) 
- el escritor posee el marco interpretativo del lector, el saber poder;

- ese diálogo existe para el escritor, es decir, mantener las riendas de la interpretación

- la lectura es un espacio trans/geográfico y atemporal

El lector es una invención escritural. La mirada del escritor dialogante obvia la posibilidad de un lector nativo, quien resulta una propuesta casi utópica. El lector constructo de Jones Mathama es un extranjero. Ante la posibilidad de un lector nativo debemos asumir como respuesta única aquella que encontramos en una dedicatoria de Ekomo y analizada en este dossier por Clelia Rodríguez al enfrentar la novela de María N'süe. Dicha novela comienza aludiendo al gesto imposible de una lectora nativa en su dedicatoria: "A Nnanga, mi vieja amiga, lástima que no sepa leer". ${ }^{5}$ Siendo en ese caso la lectoescritura un caso de diálogo utópico.

Jones Mathama, por su parte, nos coloca ante dos proyectos de lectura: de un lado, leer es un acto de reorganización de realidades; y, de otro lado, una vez que el lector se asume como un gran ausente, se torna en un acto creativo que mantiene entalpía de diversos niveles de distancia con el texto en exégesis.

\section{El LeCTOR DiALOGANTE, EL LECTOR DigITAL}

La relación entre el escritor y su lector en la novela guineano-ecuatoriana en el momento contemporáneo recuerda por su intimidad a aquella que Platón parecía creer perdida con el advenimiento de la escritura. En efecto, esa necesidad presencial que Jones Mathama explora en la primera sección de su novela en el momento colonial se materializa. El lector, sin embargo, no re/asume el diálogo que Platón exigía. Si bien el lector intenta abolir las distancias del marco de producción y recepción que apunta Kristeva al acuñar el término genotexto, abdica ante la posibilidad de ser una presencia con sus carnosidades propias en el texto que lee. El medio cibernético ejerce una interesante relación texto-lector. El lector se disciplina, para dejar de poseer al texto. Su proceso de lectura no será ya dotar al texto de sentidos posibles, como parte del placer de la lectura. Asedia al escritor para dejarse guiar por las nociones del escritor, por la interpretación del escritor de su propia obra. El lector ya no interroga al texto, el escritor es el objetivo del diálogo.

El escritor, muchas veces en contra de su marco de intencionalidades, por medio de entrevistas, conversaciones por correo electrónico o amigándose en Facebook, mantiene el poder del campo de significaciones de su texto. La lectura se convierte en un espacio casi redundante, en ese marco de recepción. El texto se percibe insuficiente sin ese diálogo que la oratura sostenía y la literatura prescindía. De allí que algunos

\footnotetext{
Véase sobre esta frase, el texto en este mismo volumen de Clelia Rodríguez.
}

Revista Iberoamericana, Vol. LXXX, Núms. 248-249, Julio-Diciembre 2014, 1081-1095 
lectores críticos reescriban ensayos desde la nueva hermenéutica de lo que e/la autor/a explicita en una entrevista. La voz del autor no cede ante la voz del texto.

El lector/escritor pertenece a un aquí/ahora que Facebook y la comunicación cibernética procuran. Es en el aquí/ahora cibernético cuando el posicionamiento del lector en esas coordenadas propuestas por Jones Mathama -quien guía a su lector por el marco interpretativo- se fortalecen y transforman, con la presencia de Facebook, la nación cibernética que tiene mas ciudadanos que la China y una ciudadanía ejercitada por lecto-escritores.

Así desde el texto de Jones, el lector encarnado y silente, y desde el de Evita necesitado de un doble código visual y escrito, amen de un mediador, el prologuista corrector nos hace propuestas de lectura que de alguna manera moldean/anticipan, resumen paradigmáticamente el acercamiento que como lectores asumimos a la hora de enfrentar textos guineano ecuatoriales. Leer es estar allí físicamente, dialogar en entrevistas o enviar mensajes cibernéticamente. El acto de leer no termina al cerrar el libro.

Contrario a Barthes y su propuesta del autor muerto, o al menos desaparecido, paradigma teórico central de la teoría de la recepción de la posmodernidad en el caso de la escritura guineano-ecuatoriana contemporánea, el escritor se vuelve un ente en consulta constate, policía-las mas veces renuente-de la interpretación. En consecuencia el lector se asume como un sujeto en necesidad continua de la regulación del escritor y el arbitrio de sus provocaciones. Así las cosas, el lector no ha leído válidamente si antes no hace su viaje, entrevista al autor, se enfanga los zapatos en alguna calle sin pavimentar en Bata. El lector no lee a menos que sea de la mano de quien escribe. Existe una inmediatez en la pertenencia del texto que duelo haber perdido. El libro ya no me pertenece como lectora.

Así las cosas, desde abril del 2009 Juan Tomas Ávila Laurel, escritor polígrafo de Annabón, Guinea Ecuatorial y yo, su lectora, mantenemos una curiosa conversación por correo electrónico, luego de haberle reclamado por qué no contestara mi invitación de amigarnos por Facebook. "lola aponte, hermana espero que vayas bien. Aquí estoy en Malabo con mucho trabajo este mes pero ya iremos aclarando el campo. El Facebook lo hice porque cierta profesora norteamericana solo podía comunicarse por tal medio para que le explicara mis ensayos". El escritor, ente vivo, como personaje de un thriller, entrevista a entrevista, pregunta a pregunta de su insaciable lector, va levantándose una y otra vez de la muerte que le adjudican Barthes, Eco y Sontag; dilucida su texto e interviene en contra de posibles y muy erradas lecturas. La autoridad del escritor no cesa, pese a sí mismo en muchos casos. Entrevistas, videos, presencia en congresos y Facebook son reescrituras explicativas del texto y sus misterios. El escritor convertido en su propio prologuista, interventor y corrector de significaciones, renuente y lleno de preguntas, quizás de él mismo.

En este marco la novela Arde el monte de noche de Ávila Laurel mantiene un juego con el lector, pues promete develar un secreto que se guarda finalmente.

Revista Iberoamericana, Vol. LXXX, Núms. 248-249, Julio-Diciembre 2014, $1081-1095$ ISSN 0034-9631 (Impreso) 
¿Empecé diciendo que nunca supe si mi abuelo loco? ¿Dije alguna vez que no sabía lo que era? Parte de lo que era lo descubrimos cuando entramos en su habitación. De la misma y de lo que vimos hablaré más tarde. (61)

Esta promesa de hacernos el recuento pormenorizado de la habitación del abuelo donde se encontrarán claves del texto se continua repitiendo una y otra vez, para dejarse incumplida al final del texto. Si el Facebook sirve para asegurase que toda profesora norteamericana logre dar con claves de explicación del texto esta novela veda ese acuerdo.

El texto, de un lirismo excepcional, en el que como lectores atestiguamos que lo sublime esta escrito con una de sus bases en la pregunta. Recrea el proceso preletra de la entrevista del antropólogo Manuel, a cuyo cuestionario responde en un lapso de dos días. Esto nos explica el personaje quien se declara casi iletrado.

Así en lugar del tradicional proceso de exégesis del texto nos hallamos en la lectura como proceso de isogesis, donde se colocan interrogantes referenciales del autor no incluidas ni contemplados en el texto mismo. Anécdotas de la vida cotidiana de la isla de Annobón, pensamientos secretos, hábitos ocultos de la familia narrada, que suponen forzar al escritor pre/escritura a explicar lo que no aparece en la novela. La entrevista y la visita se hacen imprescindibles en este texto, como medio de recopilar la historia de la isla de Annobón. Preguntas para la interpretación histórica, pero que el escritor las toma como formas estéticas geno textuales. El texto se va explicando a sí mismo insistentemente teniendo la pregunta-lectora como base escritural. Redacta la posible pregunta para luego no contestarla o al menos no contestarla cabalmente o hacerlo muy en clave.

El texto comienza con una canción simple en la cual el escritor alterna annobonés con español en un principio, para luego transcribirla en la lengua de su isla natal solamente:

\section{Maestro: Alee tire usted un poco}

Todos: Alewa

Lo de tire usted un poco también podía ser tirad vosotros un poco tiren de el un poco o tirad de él un poco. ¿Sabéis por que podía ser cualquiera de las versiones? Porque la legua en la que se dice esto no tiene usted pero el "maestro" se dirige a "todos" se dirige a ellos con respeto. (11)

El escritor es intérprete, relator de claves, traductor. Así el texto se vuelve explicación de texto con explicaciones minuciosas y detalladas. En una estrategia paradójica las pretendidas respuestas explicativas son más misteriosas y con menos claves que las procuradas preguntas. La presencia de ese lector que para Evita era un proyecto y para Jones Mathama un desconocedor, para Ávila Laurel es un interrogador. "¿[A]lguien sabe lo que es? Es una cosa que ocurre en mi isla, situada un poquito abajo del Ecuador.

Revista Iberoamericana, Vol. LXXX, Núms. 248-249, Julio-Diciembre 2014, 1081-1095 ISSN 0034-9631 (Impreso)

ISSN 2154-4794 (Electrónico) 
Si hubiera estudiado geografía os diría de todos los grados y minutos..."

Y más adelante intenta explicar a una voz que no escuchamos lo que acaba de decir: "¿lo de escueta pero profunda canción? En aquella isla sus habitantes viven de la pesca, pero de una pesca que realizan casi con sus manos, y sobre la mar. Entonces para ir a la mar navegan en frágiles cayucos".

La respuesta de Ávila Laurel a la presencia del receptor no explica el tema propuesto por quien pregunta. Teóricamente podemos ver cómo es cercana a las propuestas de Jauss en su Rezeptionsåsthetik, en la que explica la recepción del arte por su audiencia. Si la teoría tradicional había enfocado en el geno-tópico Jauss mira el papel decididor del receptor. Es la audiencia/los lectores quienes determinan el carácter estético del libro y establecen su lugar en la historia estética de las letras. Al contemplar la audiencia receptora Jauss se interesa en dar cuenta de lo que nomina como Erwartungshorizot que ha sido hispanizado como "horizonte de expectativas". El término se utiliza en distinción del "horizonte de expectación" en el cual el autor asume a su audiencia (177).

En este caso ejemplificado por Ávila Laurel, Jauss propondría la posibilidad que al producir un texto en un marco de asumir al lector se destruya la posibilidad de lecturas fuera del genoma y quede el acto de escribir/relatar y leer/preguntar circunscrito al marco de producción. Es decir que interpretación y producción de signos abolan la grieta que adjudica significaciones. Para ello el escritor annobonés de Guinea Ecuatorial produciría en términos teóricos un texto que asuma y aclare dudas de la lectura a cada paso. Un libro que atienda la recepción de sus claves, un texto guiado en sus niveles denotativos y connotativos. En la estructura de Arde el monte de noche eso parece ser el principio regidor, volviendo para ello a un productor de signos ajeno a la escritura, cercano al productor del narratio platónico.

Jauss toma la pretensión marxista de texto literario como denuncia y locus para provocar cambios sociales como el texto paradigmático de ese proceso en el que el autor asume el horizonte de expectación en su escritura. En el caso del escritor guineoecuatoriano dos elementos provocan relatar el espacio de expectación del lector: la necesidad de saber de quien entrevista, la necesidad de narrar del personaje entrevistado.

Sin embargo, el gesto de crear un horizonte de expectación como modalidad narrativa no tiene ningún elemento en común por lo aplicado por Jauss a la escritura de creación de denuncia y creación de nuevas sociedades. El polígrafo guineo-ecuatoriano se decide por logogrifo como respuesta. O más bien como no respuesta, pues ante cada pregunta la respuesta ya circunvala posibles respuestas o apunta en una dirección fuera del marco que la pregunta supone. Veamos:

Por qué ocurren las desgracias. Nunca habrá una respuesta. No la tenían los sacristanes y en aquel tiempo yo creía que lo sabían todo. Nunca habrá una respuesta. Lo que a veces conocen los hombres es cómo comenzó una historia o un hecho público que desató la maldad de cualquier situación. Hay algunos que se consuelan cuando conocen las

Revista Iberoamericana, Vol. LXXX, Núms. 248-249, Julio-Diciembre 2014, $1081-1095$ ISSN 0034-9631 (Impreso)

ISSN 2154-4794 (Electrónico) 
primeras causas aparentes. (...) Los hay también que arrugan los labios y fruncen el ceño cuando remontan la historia y llegan a la primera causa aparente. Bueno en mi isla cuentan cosas que no son solamente para comer y beber. Lo digo por si alguno dijera que no estoy queriendo decir nada. (114)

Las preguntas se articulan como formas de avanzar la escritura sobre un mundo que sigue siendo ignoto tras más de cincuenta años de escritura constante. En este caso, como en los dibujos de Evita, las explicaciones son logogrifos y enigmas que relatan la imposibilidad de traducir un mundo en otro. Volvemos a ser los lectores que Mathama Jones devuelve al barco.

\section{BiBLIOGRAFÍA}

Ávila Laurel, Juan-Tomás. Arde el monte de noche. Madrid: Calambur, 2009.

Barthes, Roland and Stephen Heath. Image, Music, Text. New York: Hill and Wang, 1977. Derrida, Jacques. Of Grammatology. Baltimore: Johns Hopkins UP, 1976.

Writing and Difference. Chicago: U of Chicago P, 1978.

Eco, Humberto. Lector in Fábula: La cooperación interpretativa en el texto narrativo. Barcelona: Lumen, 1987.

Evita, Leoncio. Cuando los combes luchaban: (novela de costumbres de la Guinea Española). Madrid: Consejo Superior de Investigaciones Científicas, 1953.

Iser, Wolfgang. The Act of Reading: A Theory of Aesthetic Response. Baltimore: Johns Hopkins UP, 1987.

Jauss, Hans Robert. Experiencia estética y hermenéutica literaria. Madrid: Taurus, 1992. Jones, Mathama D. Una lanza por el boabi. Barcelona: 1962.

Kristeva, Julia. Ensayos de semiótica poética. Madrid: Planeta, 1976.

Onomo-Abena, S. "Sujeto cultural colonial y producción literaria en Guinea

Ecuatorial. Lectura sociocrítica del prólogo de Cuando los combes luchaban (1953) de Leoncio Evita". EPOS. XVIII (2002) 215-229. <http://e-spacio. uned.es/fez/eserv.php?pid=bibliuned:Epos-29FFD912-7879-2554-4B504E5B69C3B145\&dsID=Documento.pdf>. 27 mayo 2014.

Platón. Fedro. Madrid: Alianza, 1998.

Turner, Victor W. "Betwixt and between: The Liminal Period in Rites De Passage." Symposium on New Approaches to the Study of Religion: Proceedings of the 1964. Annual Spring Meeting of the American Ethnological Association (1971): 4-20. 
